\title{
STEEL SECTOR IN POLAND AND ITS CONDITION AFTER ACCESSION TO THE EUROPEAN UNION
}

\author{
Grondys Katarzynat ${ }^{1}$, \\ Beata Ślusarczyk ${ }^{2}$
}

\begin{abstract}
Recent several years of Polish metallurgy have seen deep changes and both organizational and ownership transformations. Steel companies, frequently subject to restructuring and continuous improvement in their operation, developed a highly competitive position in the European market. The requirements connected with Poland's accession to the EU has considerably contributed to positive changes which occurred in the sector. However, they had also impact on the extent to which Polish metallurgy was affected by the aftermath of world crisis.
\end{abstract}

Key words: steel sector, economic crisis, reorganization

JEL code: $L 61$

Introduction

The goal of metallurgy sector in the EU, being one of the biggest steel suppliers worldwide, is to strive for maintaining production in steel sector at possibly highest level, in consideration of transformations and trends which occurred in world market (Biuletyn Informacyjny EDLESI No. 2, 2007). Compared to other markets, steel, as a product of global character, plays significant role in the EU economy in the aspect of competitiveness.

Steelworks located within the EU constitute an important source of employment. Steel is an essential material resource for other sectors of the industry. Metallurgical products are a fundamental material for many areas of the economy and significantly affect competitiveness of other industrial products. Ensuring possibly best quality of steel products is necessary for maintaining highly competitive position among European steel manufacturers.

Emerging new products and processes which satisfy ever-changing expectations of consumers determine transitions in European metallurgy. The effects of these changes, however, must meet the requirements of sustainable development. European steel sector is subject to continuous structural changes and this process was particularly noticeable in 2007 when new competitors appeared in BRIC countries (Brazil, Russia, India and China). Previous crises in metallurgy sector were caused by rapid changes in demand, caused by economic phases. Suddenly, increased demand could not be satisfied immediately, which was the reason for frequent stoppages in consumption manufacturing and investment activity.

\section{Polish Metallurgy Sector in 2004-2009}

Metallurgy in Poland also experienced a number of changes in recent years and takes a part of huge European steel production today.

Manufacturing in the sector of steel and iron covers (Brudzyński, 1997):

O production of pig iron from ores or scrap metal,

$\circ$ production of specular pig iron, high-carbon ferromanganese and ferrophosphorous alloys,

\footnotetext{
${ }^{1}$ Czestochowa University of Technology, The Management Faculty, Armii Krajowej 19B, 42-200 Czestochowa, email: kgrondys@zim.pcz.pl

${ }^{2}$ Czestochowa University of Technology, The Management Faculty, Armii Krajowej 19B, 42-200 Czestochowa, email: jagoda@zim.pcz.czest.pl
} 
O production of steel in converters or blast furnaces,

○ production of e.g. hot-rolled products together with continuous casting products etc.,

$\circ$ production of granular iron.

Before Polish steelworks were restructured (1992), they had not been able to satisfy the whole demand, despite its wide range of products. Negative financial results in metallurgy forced taking measures aimed at improvement in the state of the sector. The process of rebuilding transformed previous system of functioning of steelworks, however, it did not cause a rise in its competitiveness on an international scale. For the most of big Polish industrial companies, the necessity for survival in a competitive market (...) stimulated investment activities (Ślusarczyk, 2001). All hazardous and obsolete installations were shut down and huge investment expenditures were made to promote innovative methods of steelmaking, steel processing and casting (Talarek, 2009). The period of 1998-2000 marked the beginnings of steelworks getting out of economic crisis caused by uncompleted restructuring processes (Stachowicz, 2001).

Huge benefits were brought by a number of mergers and acquisitions, which affected rise in competitiveness and reduction in overall costs (Piotrowski, 2001). Consolidated enterprises achieved stronger position in the market and higher impact on the level of demand and steel prices. Apart from this, big companies purchased necessary resources at cheaper prices, which was reflected in their financial results (Dudała, 2006).

The restructuring renewed after 2000 has not brought the desired results connected with success in foreign markets yet (Starostka-Patyk, Kozak, 2004). Nevertheless, steel production in Poland, driven by restructuring as well as ownership and organizational transformations, is becoming, slowly but steadily, a part of European metallurgy.

Planned development of steelworks and research projects has become an integral part of those developed for the European industry, taking into consideration benefits to both suppliers and consumers of steel products throughout Europe, including Poland. Integration of Poland with the EU obliged Polish steelworks to implement changes in terms of environmental protection, stimulated by changes in legal regulations (Bartkowiak et Nitkiewicz, 2004).

The year of Poland's accession to the EU will be remembered as a very beneficial to steel producers since the prices of steel products had been long maintained at an exceptionally high level. High operational profitability, which reached ca. $15 \%$ in 2004, reminds of previous financial restructuring, which allowed, through issue of securities, for purchasing claims against steelworks (Roczny Raport Agencji Rozwoju Przemysłu, 2003).

Improving standing of Polish steelworks experienced a slump in 2005 as a result of sudden decline in prices of steel products (Baranowski, 2003). Domestic industry reached almost 4\% rise in revenues, whereas the revenues in steelworks dropped by $18 \%$. Profitability in the sector also decreased considerably and maintained at the level lower than in the whole market. However, liquidity ratios reached satisfactory levels, rising faster in steel sector than in the whole industry, which was caused by gradual limitation of production at the end of the year 2005 and it resulted in reduction in a part of steel inventory (Baranowski, 2003).

After reduction in the level of production in recent years, the year 2006 saw dynamically rising production of steel pipes among the EU countries, including Poland with share in European production at a remarkably high level. Sudden rise in demand for this type of steel products was a consequence of the demand in Chinese market which, as a result of rise in prices for oil and gas abroad, invested in their own mining sector. The decision of Chinese market was followed by manufacturers from chemical and automotive industry (Dudała, 2006). The demand for steel pipes rose also among energy and construction companies. Higher supplies to Easter markets resulted in an increase in incomes on sales in relation to previous year by nearly $25 \%$. Financial result on sales of steel products rose by nearly $300 \%$ and, against the background of the whole industry and the economy, was impressive.

This good financial results affected high profitability ratios, which improved almost 
thirtyfold, with steelworks reaching almost fivefold return on sales (Biuletyn o sytuacji finansowo ekonomicznej sektora hutniczego, CIBEH S.A., Katowice 2006). In consideration of capital intensity in metallurgy sector and long operational cycles, the obtained profitability ratios confirmed high dynamics of sales of steel products.

Liquidity ratios were also improved, with particular rise in first degree liquidity ratio, which reflects replenishment of the inventory. This result, however, had the least effect on liquidity in the industry and the whole economy than in the previous year.

The demand for steel products has risen year by year, which resulted in particular from dynamically developing economies in China, Russia, India and Brasil.

For the whole year 2007, steel sector reached overall income at the level of 31,691.8 billion PLN, which rose compared to the previous year by 19.5\%. Against the background of industrial sector and domestic economy, steel sector developed the most dynamically, with revenues on sales by $3 \%$ and $5 \%$ higher than in the whole marked compared with 2006 (Biuletyn o sytuacji finansowo -ekonomicznej sektora hutniczego, CIBEH S.A., Katowice 2006). Profitability of the sector was lower compared to profitability of the whole industry; however, the same dynamics for the rate of return was more favourable for metallurgical enterprises. Current ratio and quick ratio decreased by barely $3 \%$ compared to 2006, marking a start point for the phase of financial stability.

Favourable trends in steel sector maintained until late autumn of the year 2008, when a gradual rise in prices for all raw materials and energy used for production of steel products was observed. Incoming economic crisis caused sudden slump in production of steel products and unexpected reduction in their prices (Dudała, 2006).

In 12 months, steel sector reached total revenues at the level of $34,685.8$ million zlotys, which resulted in only $9 \%$ rise compared to 2007 . Revenues on sales against the background of the whole economy and the industry showed the lowest (7\%) growth dynamics.

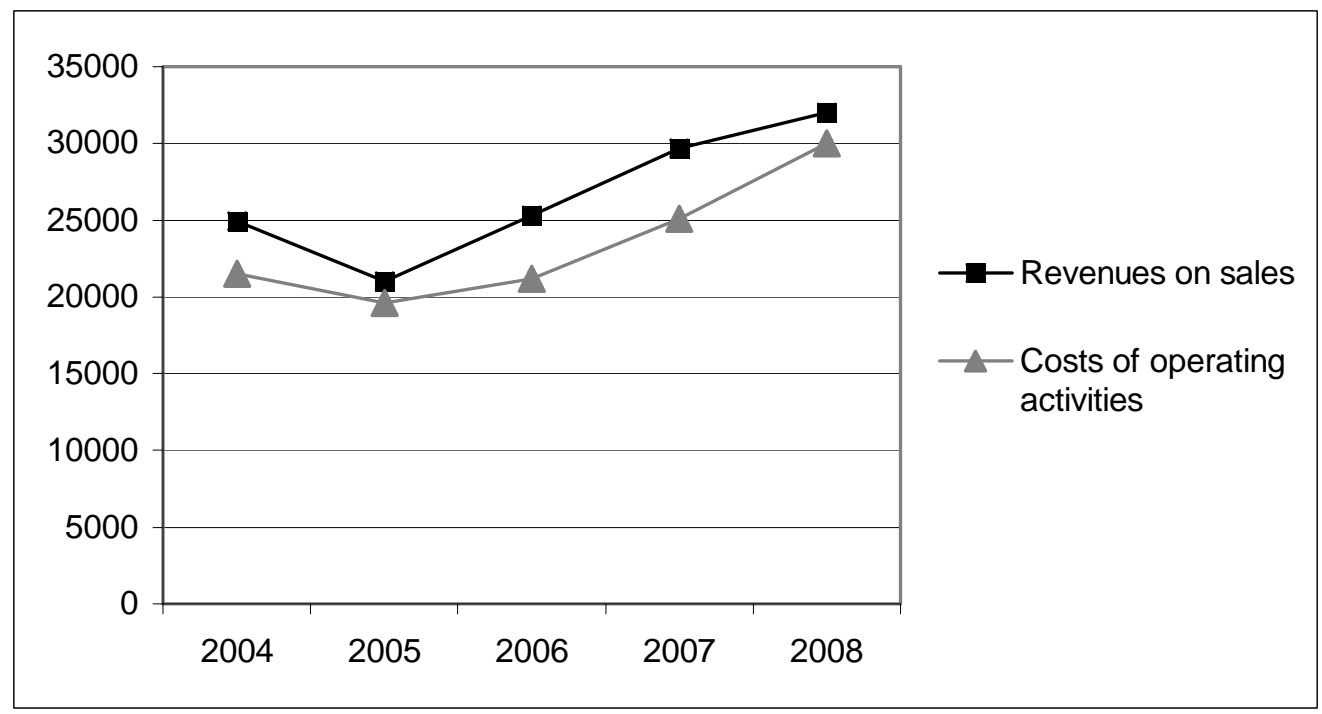

Fig. no. 1. Revenues on sales and costs of operating activities in 2004-2008

Source: Biuletyn o sytuacji finansowo -ekonomicznej sektora hutniczego, CIBEH S.A., Katowice 2004-2008.

Observation of the value of revenues on sales and costs of core activities in 2004-2008 points to a temporary slump in the period of the year 2005 and its considerable improvement in the following years and also in early quarters of 2008.

It was as late as in last quarter of 2008 when the biggest decline in financial values was observed, which resulted in reduction of profitability by half compared to 2007. Liquidity of steel companies also suffered, decreasing by $32 \%$ on average, whereas liquidity of the whole economy and the industry amounted to barely $1 \%$ less in the case of current ratio and ca. $4 \%$ for quick ratio. 
The turn of 2009 will be remembered as a period of serious decreases in price and production as a result of surplus in steel inventory. Reduction in the level of demand for steel products, particularly in China, being a strategic steel consumer, caused price stagnation. Reduced production of steel in the EU resulted in huge metal inventories, which resulted in the year 2009 becoming a year of high supply and high inventory to be getting rid of. Inventory levels in warehouses and stores of London Metal Exchange rose by $84 \%$ to reach a record-breaking amount of 5.6 billion tonnes, estimated at over 14 billion dollars (Flood, 2010). Steel sector experienced economic downturn much earlier than other sectors in the industry, which can be confirmed by revenues decreasing in the third quarter of 2008.

Last year saw extreme decline in the profits with the rise in incurred loss. This caused loss of steelworks at the level of gross $4.2 \%$ and net $2.9 \%$. The level of steel products was highest in 2008 and it reached, in 2009, the level from three years before, when limited production caused depletion of the surplus inventory.

The year 2009 turned out to be a year of intensified fight for contractors.

Unfavourable economic situation worldwide, considerable rises in energy prices, limited production and serious decline in demand caused unprofitability of a number of steelworks and their liquidation. Crisis has also left its stamp on commodity exchange abroad. Dynamics of imports and exports reduced dramatically, although previous trends of commodity exchange and trading with EU countries were maintained (op. cit., Nowoczesne ..., p. 855).

In the face of weakened world economy and fluctuations in economic situation in steel industry, steel companies are forced to implement immediate changes in their functioning, which will allow for better adjustment to current economic conditions. The process of this adaptation is reorganization, whose overriding goal is to radically order activities in each area of company (Gajdzik, 2009).

\section{Summary}

Poland, on the eve of accession to the EU, was forced to restructure steel companies in order for them to properly prepare to operate under conditions of the Community economy. Therefore, the year 2003 was the year of changes in economic and development characters, whose continuation was supposed to take until 2006 according to the program of Restructuring and Development of Steel and Iron Industry in Poland until 2006 (Roczny Raport Agencji Rozwoju Przemysłu, 2003). Reduction in prices for steel products in 2005 caused short-term downturn in steel sector, which was considerably improved after a year, when supply to Chinese market rose dynamically.

In the beginning of 2008, economic crisis emerged in steel market, thoroughly changing current strategy of operation of steel companies and their agents. Sudden slump in demand for steel products in 2009 limited production size and caused the decrease in the level of employment. The resultant material reserves caused that initial rise in steel prices slowed down. The collected inventory posed a considerable obstacle to increasing prices for steel products, posing threat of financial loss in the sector. Rise in energy prices made it impossible for Polish steelworks to get out of the crisis, limiting its competitiveness in relation to steelworks from the EU region. In order to reduce costs, a number of steel enterprises decided to close their coke plants and shut off some furnaces.

Downward tendency in steel sector was considerably higher than in the case of other branches of the industry, where crisis was characterized only by a slowdown. However, in consideration of the decision about organization of EURO 2012 in Poland, one can assume that the future of steel sector shows great promise for the domestic economy. Current and future projects and investments in transport infrastructure and construction impose high requirements on the levels of steel supply and provide an opportunity for revival of Polish steel industry. 


\section{References}

1. Baranowski M.: Limity emisji CO2 zahamują rozwój polskiego hutnictwa, Fakty. Magazyn Gospodarczy, http://www.bankier.pl/wiadomosc/Limity-emisji-CO2-zahamuja-rozwojpolskiego-hutnictwa-1587886.html

2. Bartkowiak P., Nitkiewicz T., 2004. Wdrażanie systemów zarządzania środowiskowego jako element restrukturyzacji sprywatyzowanych przedsiębiorstw [in:] Glinkowski C. (ed.): Zarządzanie zmianą. Restrukturyzacja przedsiębiorstw w strategii rozwoju gospodarczego krajów Europy Środkowo - Wschodniej, Wyd. Wydziału Zarządzania Politechniki Częstochowskiej, Warsaw.

3. Biuletyn o sytuacji finansowo -ekonomicznej sektora hutniczego, CIBEH S.A., Katowice 2004 - 2008.

4. Brudzyński R., 1997. Analiza sektora hutnictwa żelaza i stali [in:] Błaszczyk B., Cylwik A.(ed.): Charakterystyka wybranych sektorów infrastrukturalnych i wrażliwych w gospodarce polskiej oraz możliwości ich prywatyzacji, Raport Case No. 27, Warsaw.

5. Dudała R.: Hutnictwo: więcej inwestycji, więcej rur, http://www.wnp.pl/artykuly/hutnictwowiecej-inwestycji-wiecej-rur,2795.html

6. Dudała R., 2006. Jak konsoliduje się sektor hutniczy, Miesięcznik Gospodarczy Nowy Przemysł, 1481965.html

7. Dudała R.: PUDS: Wzrost cen stali jest nieunikniony, http://hutnictwo.wnp.pl/puds-wzrostcen-stali-jest-nieunikniony,107281_1_0_0.html

8. Flood, Ch.: Rynek metali przygnieciony przez zapasy, Financial Times, http://forsal.pl/artykuly/359322,rynek_metali_przygnieciony_przez_zapasy.html

9. Gajdzik B., 2009. Transformacja i reorganizacja przedsiębiorstw hutniczych w warunkach światowego kryzysu gospodarczo-finansowego, Hutnik - Wiadomości Hutnicze, No. 12/2009.

10. Piotrowski D., 2001. Motywy dokonywania transakcji fuzji i przejęć [in:] Moszkowicz M. (ed.): Strategie i konkurencyjność przedsiębiorstw po dziesięciu latach transformacji, Wyd. Wydziału Zarządzania Politechniki Częstochowskiej, Polanica Zdrój.

11. Przemysł hutniczy w Unii Europejskiej: Zmiany i możliwości, Biuletyn Informacyjny EDLESI No. 2, September 2007.

12. Roczny Raport Agencji Rozwoju Przemysłu, 2003, http://www.arp.com.pl/o_agencji/raporty_roczne.aspx

13. Stachowicz J.K., 2001. Zarządzanie procesami reorientacji strategicznej w przedsiębiorstwach przemysłów tradycyjnych, PWN, Warsaw.

14. Starostka-Patyk M,. Kozak M.: Stan obecny i perspektywy restrukturyzacji przedsiębiorstw w Polsce i wybranych krajach Europy Środkowo-Wschodniej. [in:] Glinkowski Cz. (ed.) Zarządzanie zmianą. Restrukturyzacja przedsiębiorstw w strategii rozwoju gospodarczego krajów Europy Środkowo-Wschodniej. Wyd. Naukowo-Techniczne. Warsaw, p. 279-289

15. Slusarczyk B., 2004. Rola inwestycji w osiąganiu strategicznych celów restrukturyzacji Huty Częstochowa S.A. [in:] Moszkowicz M.(ed.): Strategie i konkurencyjność przedsiębiorstw po dziesięciu latach transformacji, Wyd. Wydziału Zarządzania Politechniki Częstochowskiej, Polanica Zdrój 2001.

16. Talarek R.: Nowoczesne hutnictwo stalowe w Polsce wobec globalnego kryzysu ekonomicznego, Hutnik - Wiadomości Hutnicze, No. 12/2009. 